\title{
Narasi Fikih Kebangsaan di Pesantren Lirboyo
}

\author{
Achmad Hidayat ${ }^{1}$, Zaenal Arifin ${ }^{2}$ \\ ${ }^{1}$ Institut Agama Islam Tribakti Kediri, ${ }^{2}$ Institut Agama Islam Tribakti Kediri \\ ${ }^{1}$ achmadhidayat@gmail.com, ${ }^{2}$ zae.may13@email.com
}

\begin{abstract}
This article examines the idea of 'fikih kebangsaan' in Pesantren Lirboyo Kediri. This idea was born, after the bahstul Masa'il was carried out by Himpunan Alumni Santri Lirboyo (Himasal) by responding to issues that occurred in this country. The method used is referring to the results of the Alim Ulama National Conference regarding methods of lawmaking, including qauli, ilhaqi and manhaji. Indirectly, in an academic context, this 'fikih kebangsaan' is a branch, or further study of scientific discussion in the form of 'fikih nusantara', which is also a further specification of 'Islam Nusantara'. Within the pesantren itself, the idea of 'fikih kebangsaan' is narrated in the form of a book which is disseminated, discussed and publicized, and used as the subject of the pesantren. So that it can be seen, from here that Pesantren Lirboyo Kediri has an orientation to contribute to national problems, namely the issue of nationality. The results show that the idea of 'fikih kebangsaan' in Pesantren Lirboyo emerged on the basis of the anxiety experienced by the alumni of the Lirboyo pesanten. This idea manifests itself in the form of: a). the book that was distributed. b). discussed in a public seminar. c). used as subjects in the pesantren.
\end{abstract}

\section{Key Word: National Fiqh, Pesantren Lirboyo}

\begin{abstract}
Abstrak
Artikel ini mengulas mengenai gagasan fikih kebangsaan yang ada di pesantren Lirboyo Kediri. Gagasan ini lahir, setelah dilakukannya bahstul masa'il yang dilakukan oleh para Himpunan Alumni Pesantren Lirboyo (Himasal) dengan merespon isu-isu yang terjadi di tanah air ini. Metode yang digunakan yaitu mengacu pada hasil Munas Alim Ulama mengenai metode pengambilah hukum, di antaranya yaitu qauli, ilhaqi dan manhaji. Secara tidak langsung, dalam konteks akademik, fikih kebangsaan ini merupakan suatu cabang, atau kajian lebih lanjut dari diskusi keilmuan berupa fikih Nusantara, yang mana fikih Nusantara ini juga merupakan spesifikasi lebih lanjut dari Islam Nusantara. Di dalam pesantren sendiri, gagasan fikih kebangsaan ini dinarasikan dalam bentuk buku yang disebarluaskan, didiskusi publikkan, dan dijadikan mata pelajaran pesantren. sehingga dapat terlihat, dari sini bahwa pesantren Lirboyo mempunyai orientasi ikut andil terhadap permasalahan nasional, yaitu isu kebangsaan. Hasilnya menunjukkan bahwa gagasan fikih kebangsaan di pesantren Lirboyo muncul atas dasar kegelisahan yang dialami oleh para alumni pesanten Lirboyo. Gagasan tersebut termanifestasikan dalam bentuk: a). buku yang disebarluaskan. b). didiskusikan dalam seminar publik. c). dijadikan mata pelajaran di dalam pesantren.
\end{abstract}

Kata Kunci: Fikih Kebangsaan, Pesantren Lirboyo 


\section{Pendahuluan}

Melihat pada penelitian yang dilakukan oleh Mohamad Khoirul Fata, "Membaca Polarisasi Santri Dalam Kontekstasi Pilpres 2019”, terlihat bahwa santri terpecah menjadi dua varian. Secara tidak langsung, pengamatan yang dilakukan atas fenomena sosial tentang populisme Islam (santri) dan setiap narasi yang digaungkannya, polarisasi tersebut terwakili oleh varian santri radikal dan santri moderat. Seperti yang terjadi pada diri santri radikal, acap kali tuntutan yang dilakukan ketika turun jalan sebagai bentuk berdemokrasi, alih-alih menginginkan penegakan dasar maupun hukum negara harus menggunakan Syariat Islamiyah, atau sistem Khilafah. Narasi-narasi stereotype juga mereka labelkan terhadap pemerintah, seperti halnya antek asing, PKI, maupun \#2019Gantipresiden. Berbeda dengan santri radikal, santri moderat diidentikkan dengan Islam Nusantara, yang dinilai cocok dengan budaya, Pancasila, maupun Bhinneka Tunggal Ika. Mereka juga tidak terlibat dalam upaya memproduksi suatu wacana buruk terhadap pemerintah. ${ }^{1}$

\footnotetext{
${ }^{1}$ Mohamad Khoirul Fata, "Membaca Polarisasi Santri Dalam Kontestasi Pilpres 2019," Jurnal Dinamika Penelitian: Media Komunikasi Sosial Keagamaan Vol.18, no. 2 (November 2018).

2 Machmudi membagi varian santri menjadi tiga diantaranya yang pertama santri convergent, kedua santri radical, dan ketiga, santri global. Yon Machmudi, "The Emergence Of New Santri In Indonesia," JOURNAL OF INDONESIAN ISLAM 2,
}

Sebenarnya yang perlu diamati dari penelitian yang dilakukan oleh Khoirul Fata bukanlah terletak pada terjadinya polarisasi dalam tubuh santri. Jika menelusuri pandangan para ahli yang mengkaji fenomena polarisasi santri, varian santri radikal sebenarnya sudah masuk pada tabel catatan para peneliti sebelumnya, baik Yon Machmudi $^{2}$ maupun Najib Burhani. ${ }^{3}$ Hanya saja yang dilakukan oleh Khoirul Fata adalah penyempitan sekat pada konteks polarisasi santri, yakni pada kontestasi Pilpres 2019. Perihal yang harus menjadi perhatian dalam konteks tersebut adalah, terlihat dengan begitu jelas ada upaya secara terang-terangan untuk mengganti dasar negara menjadi Khilafah.

Upaya penegakan hukum Islam dalam versi Khilafah seperti yang diusung oleh HTI, bukanlah fenomena baru dalam sejarah pergolakan upaya mengganti dasar negara. Dalam paparannya Ali Sodiqin "Genealogi Gerakan Penegakan Syari'at Islam Di Indonesia”, jelas pada awal kemerdekaan pun upaya penegakan hukum tersebut sudah terjadi. Pada awal penentuan dasar negara yang disepakati dengan Pancasila, umat Islam

no. 11 Juni 2008$):$
https://doi.org/10.15642/JIIS.2008.2.1.69-102.
${ }^{3}$ Dalam pandangan Najib Burhani varian satri terdapa
enam varian, diantaranya tradisionalis, modernis,
neo-modernis, neo-revivalis, radikalis dan libera.
Ahmad Najib Burhani, "Geertz's Trichotomy Of
Abangan, Santri, and Priyayi: Controversy and
Continuity," JOURNAL OF INDONESIAN ISLAM 11,
no. 2 (4 Desember 2017): 329,
https://doi.org/10.15642/JIIS.2017.11.2.329-350.
https://doi.org/10.15642/JIIS.2008.2.1.69-102.

${ }^{3}$ Dalam pandangan Najib Burhani varian satri terdapa enam varian, diantaranya tradisionalis, modernis, neo-modernis, neo-revivalis, radikalis dan libera. Ahmad Najib Burhani, “Geertz's Trichotomy Of Abangan, Santri, and Priyayi: Controversy and Continuity," JOURNAL OF INDONESIAN ISLAM 11, https://doi.org/10.15642/JIIS.2017.11.2.329-350. 
terbagai tiga kelompok. Kelompok pertama umat muslim yang menerima Pancasila sebagai konsensus dasar bernegara, dan dinilai sebagai alternatif terbaik bagi bangsa Indonesia yang majemuk. ${ }^{4}$

Kedua adalah kelompok Islam nasionalis. Mereka tetap memperjuangkan formalisasi syari'at melalui partai politik. Kelompok ini diwakili oleh Muhammad Natsir, Burhanuddin Harapan, dan Sukiman. Mereka mendirikan partai Majelis Syura Muslimin Indonesia (Masyumi) yang mengakomodir semua potensi kekuatan politik kalangan umat Islam. Sedangkan kelompok yang ketiga adalah kalangan umat Islam yang menghendaki penerapan syari'at Islam dalam bernegara melalui jalur militer. Kelompok ini terkenal dengan Istilah Darul Islam/Tentara Islam Indonesia (DI/TII), yang diploklamirkan oleh Sekarmadji Maridjan Kartosoewirjo pada 7 agustus 1949. Mereka berusaha mendirikan Negara Islam Indonesia (NII) yang terpisah dengan Republik Indonesia. Dalam perkembangannya NII menyebar ke berbagai wilayah di Jawa Tengah (dipimpin oleh Amir Fattah), Sulawesi Selatan (Kahar Muzakkar), Aceh (Daud Beureuh), Kalimantan Selatan (Ibnu Hajar). ${ }^{5}$

\footnotetext{
${ }^{4}$ Ali Sodiqin, “Genealogi Gerakan Penegakan Syari'at Islam Di Indonesia," Al-Mazāhib Vol. 3, no. 1 (Juni 2015): h. 25.

${ }^{5}$ Sodiqin, h. 26-27.

${ }^{6}$ Abd Qohar dan Kiki Muhamad Hakiki, "Eksistensi
} Gerakan Idiologi Transnasional HTI Sebelum dan Jurnal Intelektual: Jurnal Pendidikan dan Studi Keislaman

Volume 10, Nomor 3, Desember 2020
Meskipun upaya penggantian dasar negara memuncak pada pembubaran HTI, tidak semerta-merta ideologi mereka ikut terkubur. Senada dengan analisis Abdul Qohar dan Kiki Muhamad Hakiki, setelah HTI dibubarkan, gerakan eks-HTI akan berpindah haluan masuk ke partai yang mempunyai kemiripan ideologi, seperti Partai Kesejahteraan Sosial (PKS), Partai Amanat Nasional (PAN), Partai Bulan Bintang (PBB), dan Partai Pesatuan Pembangunan (PPP). Hal ini dimungkinkan karena pada umumnya partai bersifat pragmatis dan tidak mementingkan latar belakang seseorang, asalkan partai tersebut mendapatkan keuntungan elektoral dari masanya. ${ }^{6}$ Selain itu, pada penyebaran ideologi melalui media pasca pembubaran juga masif dilakukan, baik media cetak maupun media online baik berupa youtube maupun instagram. Dan umumnya nama akun diganti, tetapi isinya masih menyebarkan ideologinya. ${ }^{7}$ Ini menunjukkan bahwa upaya penyebaran ideologi mereka masih dilakukan.

Di tengah hiruk-piruk kegaduhan dengan adanya paham radikal konservatif, Pesantren Lirboyo mengeluarkan suatu gagasan 'Fikih Kebangsaan' yang merupakan sebuah counter dari paham radikal konservatif tersebut. Atas dasar ini, peneliti tertarik untuk

Pasca Pembubaran," KALAM 11, no. 2 (31 Desember 2017): $\mathrm{h}$. 390 , https://doi.org/10.24042/klm.v11i2.1403.

7 Siti Nur Fitriyana, "Fenomena Dakwah Eks-HTI Pasca Di Bubarkan," Islamic Comunication Journal

Vol. 4, no. 2 (Juli 2019): h. 204-207. 
mengupas tema tentang fikih kebangsaan yang ada di Pesantren Lirboyo Kediri.

\section{Metode Penelitian}

Berdasarkan permasalahan yang diajukan dalam penelitian, maka bentuk peneliti yang digunakan adalah penelitian kualitatif dengan tipe penelitian Studi Kasus (Case Study). Dalam penelitian studi kasus ini, peneliti melakukan pengumpulan data dan informasi secara mendalam mengenai hal-hal yang berkaitan dengan narasi fikih kebangsaan di Pesantren Lirboyo Kediri. Adapun data yang menjadi acuan dalam penelitian ini terdiri atas dua jenis yaitu: ${ }^{8}$ a). data primer, yang diwakili oleh penyusun buku fikih kebangsaan, mustahiq (wali kelas), dan santri; b). data sekunder, yaitu data-data yang mendukung informasi mengenai fikih kebangsaan di luar data primer yang telah disebutkan. Baik berupa dokumentasi yang berkaitan dengan kegiatan fikih kebangsaan maupun yang lainnya.

Sedangkan metode yang digunakan untuk penggalian data di antaranya adalah: Pertama adalah wawancara, wawancara sendiri merupakan upaya pengumpulan data yang dilakukan dengan tanya jawab langsung maupun tidak langsung terhadap narasumber. ${ }^{9}$ Dalam penelitian ini, peneliti melakukan wawancara dengan penyusun buku fikih kebangsaan, mustahiq, dan santri itu sendiri sebagai data primer. Hal yang ingin digali dalam wawancara ini adalah informasi mengenai fikih kebangsaan, baik pra maupun pasca lahirnya gagasan fikih kebangsaan di Pesantren Lirboyo. Kedua adalah observasi, yang merupakan pengamatan dan pencatatan yang sistematis terhadap gejala-gejala yang diteliti. ${ }^{10}$ Metode observasi atau pengamatan ini peneliti gunakan sebagai upaya pengecekan secara langsung untuk mengetahui bagaimana narasi fikih kebangsaan di Pesantren Lirboyo. Ketiga adalah penggalian terhadap dokumentasi. Metode ini peneliti gunakan untuk mengumpulkan data tentang narasi fikih kebangsaan di Pesantren Lirboyo Kediri yang didokumentasikan untuk melengkapi data yang diperlukan.

Dalam analisis data, peneliti membagi dalam tiga tahapan, di antaranya adalah data reduction, data display, dan conclusion drawing/verification. ${ }^{11}$ Pada tahap reduksi, peneliti memilah dan memilih dari berbagai data yang ditemukan di lapangan. Peneliti mengelompokkan dan mengaitkan berbagai data yang memiliki keterkaitan dengan fikih kebangsaan di Pesantren Lirboyo. Pada tahap display, peneliti menyajikan data dengan

\footnotetext{
${ }^{10}$ Husaini Usman dan Purnomo Setiady Akbar, Metode Penelitian Sosial (Jakarta: Bumi Aksara, 1996), h. 54.

${ }^{11}$ Sugiyono, Metode Penelitan Kuantitatif, Kulitaif, dan $R \& D$ (Bandung: Alfabeta, 2016), h. 246.
}

${ }^{8}$ Jonathan Sarwono, Metode Penelitian Kuantitatif dan $\infty$ Kualitatif (Yogyakarta: Graha Ilmu, 2016), h. 209.

m 9 Abdurrahman Fathoni, Metode Penelitian dan ¿ ${ }_{0}$ Penyusunan Skripsi (Jakarta: Rineka Cipta, 2006), h. 103 
memberikan uraian singkat berupa data yang sudah terpilih berupa narasi. Sedangkan dalam tahap terakhir berupa penarikan kesimpulan. Kesimpulan ini berupa suatu gambaran atau penjelasan secara deskriptif dari sesuatu yang masih samar-samar berupa asumsi terhadap fikih kebangsaan di Pesantren Lirboyo Kediri.

Akan tetapi, dalam penelitian ini yang perlu diperhatikan adalah dalam pengalian data yang tidak bisa begitu maksimal. Hal ini terjadi, karena penelitian ini dilakukan dalam masa pandemi Covid-19, yang mengakibatkan peneliti tidak bisa leluasa dalam menggali data yang berkaitan dengan tema yang peneliti ambil.

\section{Hasil Penelitian dan Pembahasan}

\section{Motif Lahirnya Gagasan}

Fikih

\section{Kebangsaan}

Dengan melihat hasil survei yang dipaparkan dalam Forum Koordinasi Penanggulangan Terorisme Jawa Barat yang menunjukkan angka radikalisme di Jawa Barat menurun, secara tidak langsung dapat dilihat bahwa Jawa Barat yang masyarakat lokalnya mempunyai prinsip nilai asah, asih, dan asuh ini sebenarnya jauh dari tindakan radikalisme konservatif keagamaan. Akan tetapi, karena secara geografi daerah ini

\footnotetext{
12 Pikiran Rakyat, "Hasil Survei BNPT, Indeks Potensi Radikalisme di Jawa Barat Menurun - PikiranRakyat.com," diakses 4 Agustus 2020, https://www.pikiran-rakyat.com/bandung-raya/pr01322329/hasil-survei-bnpt-indeks-potensiradikalisme-di-jawa-barat-menurun.
} Jurnal Intelektual: Jurnal Pendidikan dan Studi Keislaman Volume 10, Nomor 3, Desember 2020 berdekatan dengan Jakarta yang merupakan pusat dari penyebaran radikal konservatif keagamaan, hal ini menjadikan daerah ini begitu mudah terpapar dengan faham seperti itu. ${ }^{12}$ Dalam pemantuan yang dilakukan oleh Setara Institute Jawa Barat menempati posisi pertama dalam kasus kekerasan beragama/keyakinan. ${ }^{13}$ Lebih lanjut dari pada ini, menjelang momen Pilpres 2019 santri terpolarisasi menjadi dua kategori, yaitu santri radikal konservatif dan juga santri moderat. ${ }^{14}$ Selaras dengan apa yang dirasakan oleh Himpunan Alumni Santri Lirboyo (Himasal), bahwasanya fenomena seperti itu juga dialami oleh sebagian alumni sendiri, khususnya yang berasal dari Jawa Barat. Dari sebagian alumni tersebut, mereka tidak memahami manhaj politik para masyayyih. Akibatnya, ketika mereka sudah berada di bawah akar rumput masyarakat sangat mudah terpengaruh dengan ideologi atau manhaj politik uang berbeda dengan para masyayyih. Ironisnya, perbedaan atas dasar ketidakpahaman tersebut diekspresikan dengan bentuk caci-maki terhadap para masyayikh, khususnya dari kalangan tokohtokoh NU. Kesadaran seperti inilah yang menggerakkan Himasal untuk mengkaji isuisu kebangsaan dengan prespektif fikih dengan mengadakan bahtsul masa'il.

13 Ismail Hasani, et.all, Radikalisme Agama di Jabodetabek \& Jawa Barat: Implikasinya terhadap Jaminan Kebebasan Beragamal Berkeyakinan (Jakarta: Publikasi SETARA Institute, 2011), h. 39.

${ }^{14}$ Fata, "Membaca Polarisasi Santri Dalam Kontestasi Pilpres 2019." 
Selain atas dasar kesadaran terhadap fenomena yang terjadi, alasan lain yang menopang lahirnya gagasan fikih kebangsaan ini adalah karena program pendidikan yang ada di Ma'had Aly pesantren Lirboyo adalah Fikih dan Ushul Fikih dengan takhassus (konsentrasi) Kebangsaan. Sehingga merupakan suatu kewajiban tersendiri bagi Pesantren Lirboyo untuk untuk mengupas isuisu kebangsaan dengan perspektif fikih.

Awalnya, hasil dari bahstul masa'il ini dibukukan sebagai pegangan para alumni ketika sudah berada di masyarakat. Akan tetapi, karena permintaan masyarakat umum, buku ini dicetak sampai beberapa kali untuk disebarluaskan kepada masyarakat umum. Hingga saat ini, kajian bahstul masail dengan tema kebangsaan sudah dilakukan yang ketiga kalinya, dan sudah dibukukan semua.

\section{Terminologi Fikih Kebangsaan}

Sebelum memasuki penjelasan fikih kebangsaan, perlu diketahui bahwasanya hukum itu terbagi menjadi dua, yaitu hukum mahdlah dan goiru mahdlah. Hukum madhlah ini bersifat konstan dan tidak bisa berubah (tsawabit) sesuai yang telah ditawarkan oleh berbagi ulama pendiri madzhab dan para penerusnya. Seperti halnya hukum-hukum yang ada pada salat, puasa, zakat, dan haji. Sedangkan hukum ghairu mahdlah atau muamalah ini dapat berubah-rubah (mutaghayirat) sesuai dengan keadaan suatu daerah yang dapat memengaruhinya, baik dengan tinjauan adat kebiasaan maupun kemaslahatan. Bentuk-bentuk muamalah yang masuk dalam kategori ini di antaranya adalah mumalah jual beli, ahwal alsyakhsiyah, jinayah, qadla (pengadilan), dan siyasah. ${ }^{15}$

Dari berbagai bentuk kajian muamalah ini, jika dikontekstualisasikan dalam horizon nusantara dinamakan dengan terminologi Fikih Nusantara. Yaitu hasil dari jawaban berupa hukum fikih yang mengkaji permasalahan yang ada di nusantara, dengan mendialogkan antara teks syariat dengan konteks keadaan di daerah tersebut, baik 'urf (kebiasaan) maupun kemaslahatan. Dan tentunya sama sekali tidak menyentuh hukum mahdlah. ${ }^{16}$ Seperti halnya Kompilasi Hukum Islam (KHI), hukum kehalalan suatu hewan yang memang hanya ada di wilayah nusantara ini, maupun sistem negara yang cocok dengan wilayah nusantara yang mempunyai corak yang sangat beragam.

Sesuai dengan pengantar perbedaan hukum antara mahdlah dan muamalah tersebut, dapat terlihat bahwasanya siyasah ini merupakan kajian yang masuk dalam hukum muamalah, sehingga dapat berubah seriring kebutuhan zaman. Termasuk adalah siyasah

${ }^{16}$ M. Noor Harisudin, Fiqh Nusantara: Pancasila dan sistem hukum nasional di Indonesia (Tangerang: Pustaka Compass, 2019), h. 25. 
yang nantinya akan menjadi fokus kajian fikih kebangsaan. Secara tidak langsung, dalam konteks kajian akademik, fokus kajian selalu mengalami spesifikasi lebih lanjut. Dalam hal ini, fikih kebangsaan merupakan spesifikasi lebih lanjut dari fikih nusantara.

Fikih kebangsaan merupakan suatu kajian tentang hukum fikih yang mengkaji tentang kebangsaan. Atau dengan kata lain, suatu jawaban atas fenomena tentang kebangsaan yang sering terjadi dengan menggunakan perspektif fikih, dengan perpaduan antara teks syariat dan konteks ( 'urf dan kemaslahatan) yang ada di wilayah tersebut. 'Urf yang berarti kebiasaan atau adat yang sudah disepakati, dalam konteks kenegaraan ini adalah Pancasila, Bhinneka Tunggal Ika, UUD 45, dan NKRI. Selain menggunakan teks syariat, keempat pilar sebagai kesepakatan ini juga digunakan sebagai alat analisis untuk menjawab berbagai persoalan kebangsaan yang terjadi pada bangsa Indonesia. Dengan orientasi dan pertimbangan kemaslahatan. Contoh halnya seperti mengapa hukum mencuri di Indonesia tidak diterapkan potong tangan, dan lain sebagainya.

Keempat pilar tersebut, dalam kajian bahtsul masa'il yang dilakukan oleh NU, kedudukan Pancasila tidak menggantikan kedudukan agama. Alih-alih dalam pengamalannya bisa mewujudkan tegaknya syariat Islam. Selain itu, KH. Ahmad Siddiq juga memaparkan argumentasi teologis dan fiqhi, di antaranya: 1) Mendirikan negara dan membentuk kepemimpinan dalam negara sebagai upaya memelihara keluhuran agama dan mengatur kesejahteraan dunia hukumnya wajib. 2) Kesepakaan bangsa Indonesia mendirikan Negara Kesatuan Republik Indonesia hukumnya sah dan mengikat semua golongan termasuk umat Islam. 3) mendirikan Negara Kesatuan Indonesia hukumnya sah dan harus diperhatikan. ${ }^{17}$ Sehingga sah hukumnya jika keempat pilar ini dijadikan pertimbangan dalam menggali hukum fikih tentang kenegaraan atau kebangsaan. Di satu sisi menggunakan teks yang sudah dipaparkan oleh para ulama, di lain sisi juga mempertimbangkan empat pilar yang sudah menjadi kebangsaan bernegara ini.

\section{Metode Penggalian Gagasan Fikih Kebangsaan}

Sedangkan dalam merespon isu-isu kebangsaan dalam bahtsul masa'il tersebut, pengambilan hukum tidak hanya mengacu pada metode qauli saja, melainkan juga metode ilhaqi dan juga manhaji. Apa yang dilakukan ini hasil dari rumusan Musyawarah Nasional (Munas) Alim-ulama Nahdlatul Ulama mengenai istinbatul hukmi

17 Amin Farih, "Konsistensi Nahdlatul Ulama' dalam Mempertahankan Pancasila dan Kedaulatan Negara

Islam," JPW (Jurnal Politik Walisongo) 1, no. 1 (10 Mei 2019): $\quad$ h. Kesatuan Republik Indonesia di tengah Wacana Negara https://doi.org/10.21580/jpw.v1i1.2026. 
(pengambilah hukum). Sebagaimana yang dikutip oleh A. Halimi Mustofa, Ahmad Zahro mengutarakan, yang dimaksud dari tiga metode tersebut adalah: Petama metode qauli, yaitu pengambilan sumber teks-teks empat madzhab dan juga para pengikutnya. Kedua ilhaqi, yaitu menyamakan suatu kasus yang belum ada ketentuan hukumnya dengan kasus yang sudah ada ketentuan di dalam kitab-kitab klasik. Ketiga manhaji, yaitu penyelesaian suatu masalah dengan menggunakan cara berpikir yang telah disusun oleh para imam madzhab. Prosedur praktiknya adalah menggunakan qawa'id ușuliyyah, dan qawa'id fiqhiyyah. ${ }^{18}$

Sesuai yang peneliti utarakan, bahwasanya fikih kebangsaan secara akademik merupakan spesifikasi lebih lanjut dari fikih nusantara. Konsekuensinya adalah jika mengacu pada metode penggalian hukum fikih nusantara, metode penggalian hukum fikih kebangsaan juga mengalami spesifikasi lebih lanjut. Di antara metode yang digunakan ijtihad dalam pengambilan hukum fikih nusantara adalah, maslaḥah (menghendaki kemaslahatan), 'urf (mempertimbangkan adat), sadd aż-żarīah (mencegah kerusakan), dan taḥīqu al-manāt (mendatangkan ahli untuk mengetahui ada tidaknya 'ilat keharaman). ${ }^{19}$ Keempat metode ini merupakan metode manhaji yang masuk dari sebagian qawa'id uṣuliyyah, dan qawa'id fiqhiyyah.

Karena metode tahqīqu al-manāt merupakan metode yang bersifat menggunakan pendekatan sains untuk mengetahui masih ada atau tidaknya perkara suatu alasan keharaman, maka metode ini tidak digunakan dalam melahirkan gagasan fikih kebangsaan. Contoh penggunaan metode ini adalah untuk mengetahui jenis-jenis kepiting mana saja yang hidup di dua tempat dan satu tempat. Sehingga, selain menggunakan qauli dan ilhaqi, metode yang digunakan dalam penggalian hukum fikih mengenai kebangsaan ini di antaraanya adalah

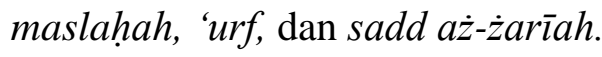

$$
\text { Sedangkan Zaini Rahman }
$$

menawarkan pedekatan yang cukup sederhana dalam menentukan suatu hukum dalam konteks tertentu. Ia meminjam istilah yang digunakan oleh 'Abid al-Jabiry yaitu bayani dengan meninjau dari nash baik al-Qut'ān, hadis, maupun fatwa ulama di kitab klasik. Selain itu juga mempertimbangkan burhani sebagai rasionalitas dalam melihat konteks. ${ }^{20}$ Menariknya, karena secara akademik fikih kebangsaan ini merupakan suatu spesifikasi kajian lebih lanjut dari fikih nusantara, lahirnya gagasan fikih Kebangsaan
18 Abdul Halim Mustofa, "Rekonstruksi Madzhab Manhaji Nahdlotul Ulama Menuju Ijtihad Saintifik N Modern," Jurnal Tribakti Vol. 02, no. 2 (Juli 2019): h. m 110-111.

๘্ర 19 Akhmad Sahal, dan Munawir Aziz, ed., Islam
Kebangsaan, Cetakan I (Bandung: Teraju Indonesia : Mizan, 2015), h. 43.

${ }^{20}$ Zaini Rahman, Fiqh Nusantara dan Sistem Hukum Nasional: Perspektif Kemashalahatan Kebangsaan, Cetakan pertama (Yogyakarta: Pustaka Pelajar, 2016), h. 233-234. 
ini seakan-akan hadir melampaui zaman. Andaian ini berdasarkan, bahwa fikih kebangsaan ini muncul pada tahun 2018, sedangkan kajian fikh nusantara lahir secara konkrit tahun 2019 yang dibawakan oleh Noor Harisudin dengan judul "Fiqh Nusantara: Pancasila dan sistem hukum nasional di Indonesia." Sedangkan yang sebelumnya dibawakan oleh Zaini Rahman dengan judul "Fiqh Nusantara dan Sistem Hukum Nasional: Perspektif Kemashalahatan Kebangsaan” tahun 2016.

\section{Bentuk-bentuk Narasi Fikih Kebangsaan}

Jika melihat motif dari latar belakang lahirnya gagasan fikih kebangsaan di atas, dapat dilihat gagasan fikih kebangsaan ini merupakan suatu counter terhadap pemahaman atau ideologi radikal konservatif keagamaan. Dalam upaya penangkalan tersebut, gagasan fikih kebangsaan disebarluaskan dalam bentuk wacana. Wacana sendiri jika merujuk pada Roger Fowler, merupakan komunkasi lisan maupun tulisan yang bertitik pandang pada kepercayaan, kategori, maupun nilai. Wacana ini sendiri mewakil pandangan dunia, institusi atau organisasi, dan juga mewakili pengalaman. ${ }^{21}$ Tentunya, dari penjelasan ini, pihak yang menerima dari sebuah wacana

${ }^{21}$ Eriyanto, Analisis wacana: pengantar analisis teks media, Cet. 1 (Yogyakarta: LKiS Yogyakarta, 2001), h. 2.

${ }^{22}$ Nurudin dan Wina Ekamawati, Komunikasi massa (Malang: Cespur, 2003), 214-23. akan mendapatkan efek dari wacana yang diterimanya. Dalam hal ini, Nurudin menjelaskan sekiranya terdapat tiga efek dari sebuah wacana; efek kognitif (pengetahuan), efek afektif (perasaan dan emosional), dan juga efek behavioral (perubahan tingkah laku). ${ }^{22}$

Maka tidak aneh, jika Pesantren Lirboyo membuat sebuah wacana dan menarasikan terus-menerus di dalam maupun di luar pesantren. Karena dakwah sendiri merupakan representasi budaya agama dari dalam merespon suatau keadaan. Baik dengan menggunakan teks maupun lisan dengan upaya berupa mendebat, menyetujui, merespon suatu permasalahan dalam sosial, politik, budaya yang dihadapi masyarakat. ${ }^{23}$ Setelah Pesantren Lirboyo membuat melahirkan gagasan fikih kebangsaan, gagasan tersebut dinarasikan dalam bentuk wacana berupa teks, dan juga lisan. Di antara penarasian wacana fikih kebangsaan tersebut adalah:

a. Buku Fikih Kebangsaan

Sesuai yang peneliti paparkan dalam motif latar belakang lahirnya gagasan fikih kebangsaan, setelah diadakan bahsul masa'il, maka hasil dari kajian tersebut dibukukan sebagai pegangan para alumni ketika sudah terjun di masyarakat. Akan tetapi, karena

\footnotetext{
${ }^{23}$ Umi Halwati, “Analisis Foucault Dalam Membedah Wacana Teks Dakwah Di Media Massa," AT-TABSYIR, Jurnal Komunikasi Penyiaran Islam Vol 01, no. 01 (Juni 2013): h. 147.
} 
peminat dari kalangan umum banyak, buku ini dicetak berulangkali dan disebarkan kepada khalayak. Dan sampai pada sekarang, kajian bahsul masa'il tentang kebangsaan sudah dilakukan yang ketiga kalinya dan sudah dibukukan semuanya.

Pada buku yang pertama, atau jilid I buku tersebut diberi judul "Fikih Kebangsaan; Merajut Kebersamaan di Tengah Kebhinnekaan”. Sesuai dengan judul sub-tema, isi buku ini memfokuskan pada pentingnya merawat kebersamaan. Untuk yang jilid II dengan judul "Fikih Kebangsaa; Menebar Kerahmatan Islam ". Buku ini fokus menyampaikan kerahmatan Islam. Buku yang ketiga dengan judul "Fikih Kebangsaan; Jihad dan Kewarganegaraan Non Muslim dalam Negara Bangsa”. Buku ini berisi menjelaskan bagaimana pemahaman jihad yang sebenarnya.

Rencananya kajian bahstul masail ini akan dilakukan sampai tahap keempat. Berbedanya dengan buku satu sampai buku tiga yang kajiannya sebagai upaya untuk menangkal gerakan kanan keagamaan. Sedangkan pada tahap terakhir ini, fokus yang dikaji adalah wacana-wacana gerakan kiri seperti komunisme, liberalisme maupun gerakan sekuler lainnya dalam bingkai kebangsaan dengan menggunakan kacamata fikih. Selain itu, hasil dari bahstul masail ini

${ }^{24}$ Pada saat peneliti menggali data, yang ditranslit baru jilid pertama

${ }^{25}$ Irfan Noor, "Identitas Agama, Ruang Publik dan akan ditransliterasikan ke dalam bahasa $\mathrm{Arab}^{24}$ dan akan dikenalkan pada dunia internasional. Baik dengan lembaga pendidikan seperti al-Azhar maupun yang lainnya.

\section{b. Seminar Fikih Kebangsaan}

Dari paparan narasumber tersebut, fikih kebangsaan yang merupakan takhassus Ma'had 'Aly juga diwacanakan dalam bentuk-bentuk dialog pubik, atau seminar. Jika mengacu pada pandangan Herbermas, diskusi publik ini masuk dalam lingkup ruang publik yang dicanangkan olehnya. Sebagaimana yang dinarasikan oleh Irfan Noor, ruang publik jka menggunakan perspektif politik, diskusi publik sebagai jembatan antara kepentingan publik dan negara. Di mana publik yang mempunyai opini menyampaikan pendapatnya atas dasar demokrasi. $^{25}$

Alasan penggaungan wacana ini jelas, bahwasanya akhir-akhir ini terdapat golongan yang ingin merubah dasar negara menjadi negara khilafah. Kehadiran fikih kebangsaan ini sebagai upaya untuk menangkis berbagai argumen yang menghendaki mendirian negara khilafah, dan juga memberikan pemahaman kepada khalayak. Pada seminar ini, atau diskusi publik ini, santri juga diperkenankan untuk memberikan suatu pemahaman yang berbeda, asalkan pemahaman atau argumen

Habermas," Jurnal Ilmiah Ilmu Ushuluddin 11, no. 1 (7 $\begin{array}{llll}\text { Maret 2016): } & \text { h. }\end{array}$ https://doi.org/10.18592/jiu.v11i1.733. 
yang dibawakan terdapat berbagai referensi yang jelas.

Selain itu, faktor lain yang mendorong diadakannya diskusi publik ini terdapat dua tujuan tertentu, pertama yaitu sebagai yang telah diungkapkan di atas, dan yang kedua sebagai penopang kapasitas santri Lirboyo sendiri. Hal ini dilakukan sebagai tunjangan para santri atas jurusan yang diampunya. Karena pada umumnya buku ajar atau fikih kebangsaan menggunakan referensi bahasa Arab, yang jelas semua pemahaman para murid tidak semuanya mempunyai standar yang sama.

Pada proses berlangsungnya seminar kebangsaan atau takhasus kebangsaan tadi, pemateri menyiapkan materi dari proyektor, santri ada yang mendengarkan dan juga ada yang mencatat. Proses penyampaian materi ini dilakukan selama dua jam, lalu disusul dengan sesi tanya jawab selama tiga puluh menit. Dan seminar ini dilakukan satu tahun empat kali, atau lebih tepatnya dalam hitungan pesantren tiga bulan sekali. sebelum masuk untuk seminar juga ada tanda tangan sebagai absen para santri. Dan untuk menjaga kekondusifan yaitu dengan ikutnya para mustahiq kelas untuk mendampingi para santri dalam seminar.

Dan untuk pemateri yang mengisinya, kalau untuk di kalangan pesantren sendiri menghadirkan narasumber sepuh. Sedangkan kalau untuk kalangan luar, yang dapat menempuh jarak jauh, pihak yang bersangkutan menghadirkan pemateri yang masih muda. Hal ini memang yang masih mudah mempunyai kekuatan fisik untuk memberikan seminar jarak jauh.

c. Kurikulum Fiqih Kebangsaan

Dalam upaya untuk memperkuat pemahaman kebangsaan pada santri, hasil bahstul masa 'il yang dibukukan menjadi buku fikih kebangsan tersebut juga menjadi bahan ajar pelajaran Ma'had 'Aly. Adanya kurikulum ini, sebagai upaya integrasi paham moderat di dalam kurikulum. Karena, hal ini dinilai dapat menjadi sebual penangkal pemahaman radikal konservatif keagamaan santri $^{26}$ terhadap pemahaman antara keislaman dan keidonesiaan. Pembagian mata pelajaran fikih kebangsaan ini di antaranya adalah, untuk buku fikih kebangsaan jilid 1 dimasukkan pada Ma'had 'Aly semester I dan II, buku fikih kebangsaan 2 untuk semester III dan IV, sedangkan untuk buku fikih kebangsaan 3 rencananya akan dimasukkan pada semester V dan VI.

Metode pembelajarannya tidak ada ketentuan dari pimpinan Ma'had Aly. Semua diserahkan kepada mustahiq masing-masing. Hal ini karena dalam proses pembelajaran semua santri tidak bisa disamakan semuanya.

${ }^{26}$ Khotimah Husnul, "Internalisasi Moderasi Beragama Dalam Kurikulum Pesantren," RABBANI Jurnal Pendidikan Agama Islam Vol. 01, no. 01 (2020): h. 26. 
Maka dalam hal itu, semua diserahkan kepada mustahiq masing-masing yang mengetahui karakter santri yang diajarnya. Ada yang bermetode presentasi seperti di kalangan kampus pada umumnya, ada juga yang bersifat ceramah. Kalau untuk mengenai ceramah, evaluasi yang digunakan adalah sebuah pertanyan kepada santri dalam waku pembelajaran. Apakah santri tersebut paham atau tidak.

Dengan adanya gagasan fikih kebangsaan ini, dan upaya penarasian wacana di dalam persantren terlihat bahwa pesantren mempunyai orientasi baru. Karena pada umumnya, dengan pertimbangan tersendiri, pesantren yang merupakan suatu subkultur dalam masyarakat, lebih memilih menutup diri dibandingkan ikut terlibat dalam masyarakat. Sehingga terlihat, pesantren seakan-akan memposisikan sebagai golongan elit dari masyarakat. Ditambah lagi, keilmuan yang selalu dikaji mengalami alienasi, tidak menyentuh pada tataran masyarakatan. Sehingga mengakibatkan pesantren seakanakan pesantren tidak bagian dari masyarakat sendiri. $^{27}$

Dengan adanya berbagai macam bentuk penarasian fikih kebangsaan di Pondok Pesantren Lirboyo terlihat bahwa pesantren sebagai subkultur dari masyarakat

27 Zaenal Arifin, "Pergeseran Paradigma Pesantren," Jurnal Pemikiran Keislaman 22, no. 1 (3 Maret 2013): h. 54

28 Jika melihat Menggerakkan tradisi: esai-esai pesantren Gus Dur, atau Nuasa Fikih Sosial KH. Sahal yang dulunya mempunyai orientasi terhadap pengembangan masyarakat, ${ }^{28}$ lalu menutup diri dengan fokus mencetak sumber daya yang mempuni, kini dalam hal ini pesantren Lirboyo mempunyai orientasi langsung pada ranah nasional. Yaitu dengan adanya upaya memberikan sumbangan pemikiran untuk mempertahankan keutuhan bangsa negara.

\section{Kesimpulan}

Munculnya gagasan fikih kebangsaan di Pesantren Lirboyo atas dasar kegelisahan yang dialami oleh para alumni Pesanten Lirboyo. Sehingga, gagasan ini merupakan suatu upaya dalam menangkal faham radikal konservatif keagamaan sekaligus upaya penguatan paham moderat dalam beragama. Dalam pengambilan hukum atau gagasan ini menggunakan qauli, ilhaqi, dan juga manhaji sebagaimana yang telah ditawarkan oleh NU dalam pengambilah keputusan. Secara tidak langsung gagasan ini merupakan kajian lebih lanjut dari rumpun keilmuan berupa fikih nusantara, yang mana fikih nusantara ini juga merupakan cabang atau spesifikasi lebih lanjut dari Islam Nusantara.

Bentuk bentuk narasi fikih kebangsaan yang ada di Pesantren Lirboyo tertuang dalam bentuk: a). buku yang disebarluaskan. b). didiskusikan dalam seminar publik. c).

Mahfud, dapat terlihat bahwa kedua tokoh ni menginginkan supaya pesantren secara langsung mempunyai peran aktif dalam masyarakat 
dijadikan mata pelajaran di dalam pesantren. dari berbagai bentuk narasi fikih kebangsaan yang ada menunjukkan bahwa Pesantern Lirboyo mempunyai orientasi dalam ikut andil menyelesaikan permasalahan publik, yaitu kebangsaan.

\section{Daftar Pustaka}

Arifin, Zaenal. "Pergeseran Paradigma Pesantren." Jurnal Pemikiran Keislaman 22, no. 1 (3 Maret 2013). https://doi.org/10.33367/tribakti.v22i 1.57 .

Burhani, Ahmad Najib. “Geertz's Trichotomy Of Abangan, Santri, and Priyayi: Controversy and Continuity." JOURNAL OF INDONESIAN ISLAM 11, no. 2 (4 Desember 2017): 329. https://doi.org/10.15642/JIIS.2017.11. 2.329-350.

Eriyanto. Analisis wacana: pengantar analisis teks media. Cet. 1. Yogyakarta: LKiS Yogyakarta, 2001.

Farih, Amin. 'Konsistensi Nahdlatul Ulama' dalam Mempertahankan Pancasila dan Kedaulatan Negara Kesatuan Republik Indonesia di tengah Wacana Negara Islam." JPW (Jurnal Politik Walisongo) 1, no. 1 (10 Mei 2019): 1. https://doi.org/10.21580/jpw.v1i1.202 6.

Fata, Mohamad Khoirul. "Membaca Polarisasi Santri Dalam Kontestasi Pilpres 2019." Jurnal Dinamika Penelitian: Media Komunikasi Sosial Keagamaan Vol.18, no. 2 (November 2018).

Fitriyana, Siti Nur. "Fenomena Dakwah EksHTI Pasca Di Bubarkan." Islamic Comunication Journal Vol. 4, no. 2 (Juli 2019): 15.

Harisudin, M. Noor. Fiqh Nusantara: Pancasila dan sistem hukum nasional di Indonesia. Tangerang: Pustaka Compass, 2019.

- Pengantar Ilmu Fikih. Surabaya: Pena Salsabila, 2016.

Husaini Usman, dan Purnomo Setiady Akbar. Metode Penelitian Sosial. Jakarta: Bumi Aksara, 1996.

Husnul, Khotimah. "Internalisasi Moderasi Beragama Dalam Kurikulum Pesantren." RABBANI Jurnal Pendidikan Agama Islam Vol. 01, no. 01 (2020).

Ismail Hasani, et.all. Radikalisme Agama di Jabodetabek \& Jawa Barat: Implikasinya terhadap Jaminan Kebebasan Beragama/ Berkeyakinan. Jakarta: Publikasi SETARA Institute, 2011.

Jonathan Sarwono. Metode Penelitian Kuantitatif dan Kualitatif. Yogyakarta: Graha Ilmu, 2016.

Machmudi, Yon. "The Emergence Of New Santri In Indonesia." JOURNAL OF INDONESIAN ISLAM 2, no. 1 (1 Juni 2008): https://doi.org/10.15642/JIIS.2008.2.1 .69-102.

Mustofa, Abdul Halim. "Rekonstruksi Madzhab Manhaji Nahdlatul Ulama Menuju Ijtihad Saintifik Modern." Jurnal Tribakti Vol. 02, no. 2 (Juli 2019).

Noor, Irfan. "Identitas Agama, Ruang Publik dan Post-Sekularisme: Perspektif Diskursus Jurgen Habermas." Jurnal Ilmiah Ilmu Ushuluddin 11, no. 1 (7 Maret 2016): 61. https://doi.org/10.18592/jiu.v11i1.733

Nurudin, dan Wina Ekamawati. Komunikasi massa. Malang: Cespur, 2003.

Qohar, Abd, dan Kiki Muhamad Hakiki. "Eksistensi Gerakan Idiologi Transnasional HTI Sebelum dan Pasca Pembubaran." KALAM 11, no. 2 (31 Desember 2017):

365. 
https://doi.org/10.24042/klm.v11i2.14 03.

Rahman, Zaini. Fiqh Nusantara dan sistem hukum nasional: perspektif kemashalahatan kebangsaan. Cetakan pertama. Yogyakarta: Pustaka Pelajar, 2016.

Rakyat, Pikiran. "Hasil Survei BNPT, Indeks Potensi Radikalisme di Jawa Barat Menurun - Pikiran-Rakyat.com." Diakses 4 Agustus 2020. https://www.pikiranrakyat.com/bandung-raya/pr01322329/hasil-survei-bnpt-indekspotensi-radikalisme-di-jawa-baratmenurun.

Sahal, Akhmad, dan Munawir Aziz, ed. Islam Nusantara: Dari Ushûl Fiqh Hingga Paham Kebangsaan. Cetakan I. Bandung: Teraju Indonesia: Mizan, 2015.

Sodiqin, Ali. "Genealogi Gerakan Penegakan Syari'at Islam Di Indonesia." $\mathrm{Al}$ Mazāhib Vol. 3, no. 1 (Juni 2015): 21.

Sugiyono. Metode Penelitan Kuantitatif, Kulitaif, dan $R \& D$. Bandung: Alfabeta, 2016.

Umi Halwati. "Analisis Foucault Dalam Membedah Wacana Teks Dakwah Di Media Massa." AT-TABSYIR, Jurnal Komunikasi Penyiaran Islam Vol 01, no. 01 (Juni 2013).

Wahid, Abdurrahman. Menggerakkan tradisi: esai-esai pesantren. Cet. 1. Yogyakarta: LKis, 2001. 